\title{
Akibat Hukum Bagi Pembeli Yang Beriktikad Buruk
}

\author{
Paula Swandayani Hartanto \\ Fakultas Hukum Universitas Surabaya \\ Email: paula.hartanto@gmail.com
}

\begin{abstract}
Abstrak. Hubungan hukum atau perikatan dalam hukum perdata bisa lahir dari dua sumber, baik karena persetujuan atau perjanjian, maupun karena undang-undang. Lahirnya perikatan di antara dua pihak atau lebih tentu memberikan akibat hukum bagi masing-masing pihak, berupa hak dan kewajiban. Setiap pihak memiliki hak dan kewajiban yang berbeda-beda. Demikian juga dalam suatu perjanjian jual beli. Penjual dan pembeli masing-masing telah membuat kesepakatan, baik tertulis atau tidak, mengenai apa saja hak-hak dan kewajiban-kewajiban yang harus dipenuhi untuk melaksanakan suatu perjanjian. Para pihak pada hakikatnya dianggap memiliki iktikad baik dalam membuat dan melaksanakan suatu perjanjian, sampai terbukti sebaliknya. Penelitian ini berusaha membahas persoalan atas suatu kasus jual beli dengan harga yang tidak wajar dan hubungannya dengan iktikad baik dari pihak pembeli apabila ditinjau dari Kitab Undang-Undang Hukum Perdata dan putusan-putusan hakim, serta doktrin para ahli. Lebih jauh, penelitian ini mengidentifikasi akibat hukum bagi seorang pembeli yang membeli barang dengan harga yang tidak wajar. Penelitian dilakukan dengan metode yuridis normatif dan menghasilkan kesimpulan bahwa seorang pembeli seharusnya memiliki rasionalitas dan pengetahuan atas kepatutan yang ada di masyarakat. Harga yang tidak wajar sudah cukup menjadi indikator bagi pembeli untuk curiga atau menduga bahwa ada sesuatu yang tidak beres dengan transaksi jual beli yang sedang dilakukan apabila pembeli tersebut memang beriktikad baik.
\end{abstract}

Kata Kunci: Iktikad Baik, Perikatan, Perjanjian Jual Beli.

\section{PENDAHULUAN}

Kehidupan manusia dewasa ini tidak dapat dilepaskan dari transaksi jual beli. Hampir setiap bagian dari kehidupan manusia tidak jauh dari konsep jual beli. Untuk memenuhi kebutuhan dasar manusia saja, jual beli hampir pasti terjadi. Mulai dari sandang (pakaian), pangan (makanan), bahkan papan (tempat tinggal).

Jual beli sendiri tidak terjadi secara tibatiba dalam kehidupan manusia. Mulanya manusia hanya melakukan tukar menukar barang atau jasa untuk memenuhi kebutuhannya sehari-hari. Sistem ini biasa dikenal sebagai barter. Namun dalam praktiknya, sistem barter memiliki banyak kelemahan sehingga manusia berusaha mencari sistem baru untuk menggantikan sistem barter. Kelemahan tersebut di antaranya adalah kesulitan dalam menentukan nilai barang yang ditukarkan, kesulitan mencari orang yang memiliki kebutuhan yang dicari sekaligus membutuhkan barang/jasa yang ditawarkan, dan karena kesulitan yang terakhir ini barang yang dimiliki akhirnya terlanjur rusak sebelum berhasil ditransaksikan.

Manusia berusaha mencari suatu alat tukar menukar yang memiliki nilai stabil dan dapat diterima oleh semua orang. Setelah mencoba berbagai macam alat tukar, akhirnya manusia menggunakan uang logam dan uang kertas sampai saat ini. Bahkan dengan perkembangan teknologi saat ini, uang elektronik sudah bukan menjadi hal yang baru lagi di Indonesia maupun seluruh dunia.

Suatu perjanjian jual beli pada dasarnya tentu menetapkan segala syarat dan ketentuan yang harus dipenuhi para pihak dalam pelaksanaan perjanjian tersebut, termasuk hak dan kewajiban dari penjual dan pembeli secara jelas. Tidak dipenuhinya kewajiban oleh salah satu pihak, tentu akan membawa implikasi atau akibat tertentu bagi pihak dimaksud. Akibat 
Jurnal Ilmu Sosial dan Pendidikan

http://ejournal.mandalanursa.org/index.php/JISIP/index

Terakreditasi Peringkat 5 (No. SK: 85/M/KPT/2020)

tersebut jelas merupakan akibat hukum, yaitu sanksi yang bisa berupa denda atau hal tertentu yang telah disepakati dalam perjanjian maupun ketentuan yang sudah diatur dalam perundangundangan yang terkait dengan perjanjian tersebut. Apabila pihak yang melanggar kewajibannya masih tidak dapat melaksanakan sanksi yang dikenakan, ada akibat hukum yang lebih jauh. Pihak yang telah dilanggar haknya dapat mengajukan gugatan ke lembaga penyelesaian sengketa atau peradilan yang berwenang.

Persoalan yang akan menjadi pembahasan dalam penelitian ini bermula dari sengketa terkait jual beli mobil antara A sebagai penjual dan B sebagai pembeli. A mengaku sebagai karyawan bagian penjualan dari PT X yang merupakan produsen mobil, padahal faktanya A telah dipecat dan hanya seorang calo jual beli mobil bekas. A menawarkan beberapa jenis mobil kepada B dengan harga bervariasi, antara Rp 100.000.000,- sampai Rp 150.000.000,- per unit. Padahal harga pasaran atas mobil-mobil tersebut sekitar $\mathrm{Rp}$ 200.000.000,- per unit. Menurut A, mobil-mobil tersebut adalah sisa penjualan dari PT X yang tidak laku sehingga dijual sangat murah di bawah harga pasaran. B yang tertarik dan percaya dengan semua rayuan A kemudian membeli empat unit mobil dengan membayarkan secara sekaligus kepada A sebesar Rp 500.000.000,-. Kesepakatan antara A dan $\mathrm{B}$ adalah empat unit mobil akan diterima dalam 14 hari kerja setelah pembayaran. Setelah 14 hari kerja, A memang mengirimkan mobil kepada $\mathrm{B}$, tetapi banyaknya unit yang dikirim ternyata tidak sesuai dengan yang telah disepakati. A hanya mengirimkan dua unit mobil kepada B. A beralasan ada keterlambatan pengiriman, sehingga meminta penundaan sealama satu bulan. Setelah satu bulan berlalu, berulang kali $\mathrm{B}$ berusaha menghubungi $\mathrm{A}$, tetapi A hanya berusaha menunda-nunda dan terus meminta perpanjangan waktu. Selama tiga bulan, A masih juga tidak dapat sisa unit mobil yang belum dikirimkan. B yang merasa
Vol. 5. No. 2 Maret 2021

p-ISSN: 2598-9944 e- ISSN: 2656-6753

dibohongi kemudian membuat laporan polisi terhadap A dengan delik penipuan, juga menggugat A secara perdata ke pengadilan negeri setempat. Berdasarkan kronologi tersebut, persoalan yang akan dibahas adalah apa akibat hukum bagi pembeli yang beriktikad buruk?

\section{METODE PENELITIAN}

Metode dari penelitian ini adalah yuridis normatif, yaitu menggunakan peraturanperaturan tertentu yang memiliki hubungan atau kaitan, baik secara langsung atau tidak langsung, dengan permasalahan yang dibahas. Digunakan tiga pendekatan untuk mendukung metode penelitian tersebut. Statute Approach, yaitu pendekatan yang mengkaji dan merumuskan masalah dengan meninjau peraturan terkait. Pendekatan kedua adalah Conceptual Approach yang menggunakan doktrin-doktrin atau pemikiran para ahli. Selanjutnya digunakan juga Case Approach yang menempatkan kasus tertentu sebagai ilustrasi atau alat untuk memudahkan pembahasan dalam identifikasi atau penelitian yang dilakukan (Marzuki, 2016).

Bahan-bahan hukum yang digunakan terdiri dari bahan hukum primer dan sekunder. Bahan hukum primer adalah peraturan perundang-undangan yang digunakan sebagai pembahasan dalam penelitian. Bahan hukum sekunder adalah bahan-bahan hukum yang mampu menjelaskan bahan hukum primer, yang terdiri dari jurnal ilmiah, buku, makalah, dan sebagainya (Marzuki, 2016).

\section{HASIL DAN PEMBAHASAN}

Menurut Soeroso (2006) hubungan hukum merupakan hubungan antara dua subjek hukum atau lebih mengenai hak dan kewajiban satu pihak berhadapan dengan hak dan kewajiban pihak lainnya. Secara lebih sederhana, Nindyo Pramono (2020) mengartikan hubungan hukum sebagai hubungan yang menimbulkan akibat hukum. Akibat hukum yang dimaksud berupa hak dan kewajiban bagi para pihak yang memiliki hubungan tertentu 
Jurnal Ilmu Sosial dan Pendidikan

http://ejournal.mandalanursa.org/index.php/JISIP/index

Terakreditasi Peringkat 5 (No. SK: 85/M/KPT/2020)

tadi. Masing-masing pihak telah memiliki kesepakatan atas hak dan kewajiban apa saja yang harus dipenuhi dan dilakukan satu sama lain.

Berdasarkan Pasal 1233 Kitab UndangUndang Hukum Perdata (selanjutnya disebut KUH Perdata), perikatan bisa lahir karena persetujuan maupun undang-undang. Perikatan yang dimaksud dalam KUH Perdata adalah adanya keterikatan berupa hubungan hukum di antara pihak-pihak tertentu. Tidak hanya karena perjanjian, melainkan undang-undang juga dapat melahirkan suatu hubungan hukum.

Sebagai contoh adalah ketika terjadi kecelakaan lalu lintas di jalan, Pasal 236 Undang-Undang Nomor 22 Tahun 2009 tentang Lalu Lintas dan Angkutan Jalan (selanjutnya disebut UU LLAJ) menentukan, pihak yang menyebabkan terjadinya Kecelakaan Lalu Lintas wajib mengganti kerugian sesuai dengan putusan pengadilan. Pihak yang menyebabkan terjadinya kecelakaan memiliki kewajiban untuk memberikan ganti kerugian bagi pihak yang terkena akibat dari kecelakaan. Demikian juga pihak yang terkena akibat berhak atas ganti kerugian dari pihak yang menyebabkan terjadinya kecelakaan. Dapat dilihat bahwa perikatan antara pihak yang menyebabkan terjadinya kecelakaan dengan pihak yang terkena akibat telah diatur dalam UU LLAJ.

Terminologi persetujuan dalam KUH Perdata sebenarnya sama artinya dengan perjanjian. Perjanjian merupakan suatu peristiwa di mana seseorang berjanji kepada orang lain dan keduanya saling berjanji melaksanakan suatu hal (Subekti, 2001). Berdasarkan Pasal 1313 KUH Perdata, perjanjian merupakan suatu perbuatan dimana satu orang atau lebih mengikatkan diri terhadap satu orang lain atau lebih. Artinya KUH Perdata juga memang tidak mewajibkan suatu perjanjian dibuat secara tertulis. Pasal 1320 KUH Perdata pun "hanya" memberikan empat syarat, yaitu kesepakatan dan kecakapan para pihak, suatu hal yang bersifat tertentu, dan sebab yang tidak dilarang. Tidak disyaratkan apakah suatu perjanjian itu
Vol. 5. No. 2 Maret 2021

p-ISSN: 2598-9944 e- ISSN: 2656-6753 harus dibuat secara tertulis atau tidak, yang artinya perjanjian itu bebas bentuk. Pasal 1338 KUH Perdata secara eksplisit menegaskan bahwa perjanjian yang dibuat sesuai undangundang, berlaku sebagai undang-undang bagi para pihak yang membuatnya. Hal tersebut berarti perjanjian yang dibuat para pihak wajib dipatuhi dan dilaksanakan sesuai dengan kesepakatan.

Apabila ada pihak yang tidak melaksanakan kewajibannya, berarti di saat yang sama telah terjadi pelanggaran atas hak dari pihak lain. Pelanggaran tersebut akan memberikan akibat hukum bagi pihak yang melakukan pelanggaran, yang biasanya berupa sanksi, baik berupa denda atau bahkan pengakhiran perjanjian. Misalnya ketika terjadi suatu transaksi jual beli, penjual sudah barang tentu diwajibkan menyerahkan barang pada pembeli untuk mendapatkan haknya berupa pembayaran sejumlah uang. Pembeli berhak mendapatkan barang dengan jumlah dan spesifikasi yang telah disepakati dengan penjual sebelumnya.

Perjanjian dapat dibedakan menjadi tiga bagian, yaitu esensialia, naturalia, dan aksidentalia (Muljadi dan Widjaja, 2003). Unsur esensialia merupakan bagian yang menjadi inti dalam suatu perjanjian dan menentukan eksistensi dari perjanjian itu sendiri. Unsur naturalia bersifat bawaan (natuur) dan melekat secara diam-diam dalam perjanjian. Dijelaskan oleh Herlien Budiono (2011) bahwa unsur naturalia bersifat mengatur dalam perundangundangan untuk masing-masing perjanjian bernama. Unsur aksidentalia menjadi unsur yang diperjanjikan secara khusus oleh dan di antara para pihak sesuai kebutuhan atau keinginan, tetapi tidak diatur dalam undang-undang bagaimana hal-hal itu harus diperjanjikan. Misalnya terkait bahasa dan hukum yang digunakan dalam perjanjian, domisili hukum, dan sebagainya.

Pasal 1320 KUH Perdata memberikan syarat-syarat tertentu yang menentukan sah tidaknya suatu perjanjian, yaitu kesepakatan 
Jurnal Ilmu Sosial dan Pendidikan

http://ejournal.mandalanursa.org/index.php/JISIP/index

Terakreditasi Peringkat 5 (No. SK: 85/M/KPT/2020)

para pihak yang membuat perjanjian, kecakapan para pihak, suatu hal atau objek yang bersifat tertentu, dan suatu sebab yang tidak dilarang. Dua syarat yang disebutkan pertama merupakan syarat subjektif karena berhubungan dengan subjek atau para pihak dalam perjanjian. Syarat ketiga dan keempat merupakan syarat objektif karena terkait dengan objek perjanjian. Tidak dipenuhinya syarat subjektif memiliki akibat hukum berupa dapat dibatalkannya perjanjian dengan permintaan pembatalan oleh salah satu pihak. Sedangkan tidak dipenuhinya syarat objektif mengakibatkan perjanjian batal demi hukum, yang berarti perjanjian tersebut dianggap tidak pernah ada.

Terdapat beberapa asas yang dikenal dalam hubungannya dengan perjanjian. Asas konsensualisme dikenal dalam Pasal $1320 \mathrm{KUH}$ Perdata, yang pada intinya adalah perjanjian sudah lahir sejak terciptanya kesepakatan di antara para pihak. Asas lain yang dikenal adalah asas kebebasan berkontrak. Asas tersebut ditafsirkan secara implisit dari Pasal 1338 KUH Perdata yang mengatur bahwa semua perjanjian yang dibuat secara sah berlaku sebagai undangundang bagi mereka yang membuatnya. Makna dari ketentuan tersebut bahwa apapun isi perjanjian yang dibuat oleh para pihak akan mengikat mereka, dengan syarat perjanjian tersebut dibuat secara sah. Hal ini terkait dengan sifat dari Buku ke III KUH Perdata yang menganut sistem terbuka, sehingga para pihak memiliki kebebasan untuk membuat perjanjian sesuai dengan kebutuhan.

Asas ketiga dalam KUH Perdata adalah asas iktikad baik yang dikenal dalam dua arti, yaitu arti subjektif dan arti objektif (Webinar Nasional Kerjasama FH Unitomo dan APHK, 2020). Iktikad baik dalam arti subjektif dilihat dari kejujuran seseorang ketika melakukan suatu perbuatan hukum sebagaimana dimaksud dalam Pasal 531 KUH Perdata. Sedangkan iktikad baik dalam arti objektif, bahwa sesuai dengan Pasal 1338 ayat (3) KUH Perdata, perjanjian harus dilaksanakan dengan iktikad baik. Pengaturan asas iktikad baik secara khusus dalam KUH
Vol. 5. No. 2 Maret 2021

p-ISSN: 2598-9944 e- ISSN: 2656-6753
Perdata menunjukkan asas tersebut merupakan prinsip yang mendasar dalam ranah privat/bisnis, bahkan menjadi "ruh" dari suatu perjanjian.

W.D. Putro dan kawan-kawan (2016) menambahkan, iktikad baik objektif itu diartikan sebagai kepatutan, bahwa tindakan pembeli itu harus sesuai dengan pandangan umum masyarakat. Masih berdasarkan W.D. Putro dan kawan-kawan (2016) dengan mengutip Hoge Raad Belanda, jika dilihat dari iktikad baik secara objektif, perjanjian itu harus dilaksanakan sesuai akal sehat dan patut. Akal sehat di sini berarti terkait dengan penalaran, dan kepatutan terkait dengan perasaan. Apa yang disepakati para pihak dalam perjanjian dan kemudian dilakukan harus dilihat dari pandangan umum tentang iktikad baik, bukan sekadar dari persepsi para pihak semata. Iktikad baik dalam arti objektif pada intinya berarti tindakan-tindakan yang dilakukan para pihak sesuai dengan yang disepakati para pihak secara rasional dan patut. Kedua hal ini menjadi penting dan bersifat akumulatif, bukan alternatif. Mungkin saja apa yang dianggap patut, ternyata tidak cukup rasional, atau mungkin juga sebaliknya.

The Second Restatement menjelaskan bahwa iktikad baik itu lebih dari sekadar jujur. Termasuk juga di dalamnya larangan untuk melanggar standar nilai yang ada di masyarakat. Beberapa ahli memiliki pandangan yang beragam mengenai pembeli yang beriktikad baik. Subekti (2014) mengemukakan, pembeli yang beriktikad baik itu adalah pembeli yang sama sekali tidak mengetahui bahwa yang dia hadapi itu bukan pemilik sebenarnya. Lalu Ridwan Khairandy (2004) menyebut pembeli yang beriktikad baik itu membeli barang dengan sepenuhnya percaya bahwa si penjual benarbenar pemilik barang yang ia beli. Agus Yudha Hernoko (2008) juga menguraikan pembeli yang beriktikad baik sebagai orang yang jujur dan tidak mengetahui cacat yang melekat pada barang yang dibei. W.D. Putro dan kawankawan (2016) menyimpulkan pendapatpendapat para pakar dengan menarik beberapa 
Jurnal Ilmu Sosial dan Pendidikan

http://ejournal.mandalanursa.org/index.php/JISIP/index

Terakreditasi Peringkat 5 (No. SK: 85/M/KPT/2020)

kesimpulan tentang pengertian pembeli yang beriktikad baik, dan salah satunya adalah pembeli itu aktif meneliti fakta material dan fakta yuridis terhadap barang yang dibeli.

Secara singkat dapat dijelaskan bahwa dari pengertian-pengertian atau pendapatpendapat yang dikutip sebelumnya, bahwa rasionalitas itu menjadi suatu hal yang harus diutamakan sehubungan dengan jual beli. Baik penjual maupun pembeli, semua pihak harus berpikir secara rasional sebelum membuat kesepakatan dan melakukan tindakan tertentu. Apa yang tidak wajar, tidak rasional, dan tidak patut, seharusnya menjadi kecurigaan bagi pihak itu, dan bahkan menjadi pertimbangan untuk membatalkan pembuatan perjanjian.

Berdasarkan Pasal 533 KUH Perdata, setiap orang sebagai pemegang bezit selalu dianggap beriktikad baik sampai terbukti sebaliknya. Apabila ada pihak yang mendalilkan seseorang beriktikad buruk, maka ia harus membuktikan dalil atau tuduhan tersebut. Pasal 532 ayat (2) KUH Perdata mengatur, jika si pemegang bezit digugat dan pada akhirnya berada pada pihak yang kalah, maka ia dianggap beriktikad buruk sejak perkara diajukan.

Iktikad baik tidak hanya harus dilaksanakan di awal saat pembuatan perjanjian, dalam tahap-tahap berikutnya sampai dengan berakhirnya perjanjian pun iktikad baik tetap harus menjadi pegangan bagi para pihak. Pasal 1321 KUH Perdata mengatur bahwa suatu perjanjian tidak akan memiliki kekuatan hukum apabila ada unsur kekhilafan atau adanya paksaan atau penipuan. Ketentuan tersebut menunjukkan beberapa unsur dari iktikad baik adalah tidak adanya kekhilafan, paksaan, atau penipuan dalam pembuatan perjanjian.

Dalam pelaksanaan perjanjian, pemenuhan hak dan kewajiban para pihak menjadi implementasi dari asas iktikad baik. Telah dijelaskan sebelumnya bahwa apabila terjadi pelanggaran hak dan kewajiban, akan timbul akibat hukum tertentu sebagai konsekuensi logis atas pelanggaran tersebut,
Vol. 5. No. 2 Maret 2021

p-ISSN: 2598-9944 e- ISSN: 2656-6753

yang seharusnya berupa pengenaan sanksi tertentu bagi pihak yang melanggar.

Berbicara lebih jauh mengenai pembeli yang beriktikad baik, Mahkamah Agung juga telah menerbitkan Surat Edaran sebagai pedoman bagi hakim dalam memeriksa, mengadili, dan memutus perkara perdata di bidang jual beli, khususnya atas objek tanah. Dalam Surat Edaran Mahkamah Agung Nomor 4 Tahun 2016 tentang Pemberlakuan Rumusan Hasil Rapat Pleno Kamar Mahkamah Agung Tahun 2016 Sebagai Pedoman Pelaksanaan Tugas Bagi Pengadilan (selanjutnya disebut SEMA 4/2016) diberikan beberapa kriteria pembeli yang beriktikad baik dalam konteks jual beli tanah. Salah satu kriteria yang diberikan adalah bahwa pembelian dilakukan dengan harga yang layak. Artinya agar dapat dikualifikasikan sebagai pembeli yang beriktikad baik, sudah seharusnya pembelian dilakukan dengan harga yang layak atau harga yang wajar. Apabila kriteria dalam SEMA 4/2016 itu ditafsirkan secara a contrario, maka pembeli yang membeli tanah dengan harga yang tidak layak atau tidak wajar dapat dikualifikasikan sebagai pembeli yang beriktikad buruk.

Dalam kasus a quo, B sebagai pembeli dengan mudahnya percaya pada A yang mengaku sebagai karyawan bagian penjualan dari PT X yang merupakan produsen mobil. B tidak berusaha mencari tahu lebih lanjut atau menelusuri latar belakang dari A, apakah benar bahwa A memang karyawan dari PT X. B juga tidak berusaha mempertanyakan lebih jauh mengenai kebenaran barang yang dijual oleh A. Selain itu, B tidak memiliki kecurigaan atau prasangka yang seharusnya muncul atas penjualan mobil-mobil dengan harga di bawah harga pasaran oleh A. Sebagaimana telah dikemukakan sebelumnya, pembeli yang beriktikad baik seharusnya membeli suatu barang dengan harga yang wajar atau masuk akal. Oleh karena itu, rasionalitas menjadi sikap yang harus dikedepankan seperti telah dikemukakan sebelumnya. 
Jurnal Ilmu Sosial dan Pendidikan

http://ejournal.mandalanursa.org/index.php/JISIP/index

Terakreditasi Peringkat 5 (No. SK: 85/M/KPT/2020)

Persoalan seputar harga yang wajar ini memang pada umumnya digunakan dalam sengketa dengan tanah sebagai objek jual belinya. Demikian juga penelitian-penelitian atau jurnal ilmiah yang membahas tentang pembeli yang beriktikad baik, pada umumnya menggunakan persoalan jual beli tanah sebagai objek penelitiannya. Namun sebenarnya dalam praktik tidak hanya jual beli tanah yang riskan akan persoalan. Jual beli atas barang-barang lain tidak jarang juga rawan dengan masalah. Pembelian suatu barang dengan harga yang tidak wajar atau tidak masuk akal sebenarnya secara praktik seringkali berujung pada dugaan terjadinya suatu tindak pidana.

Tindak pidana yang dimaksud di sini adalah tindak pidana penadahan sebagaimana diatur Pasal 480 ke-1 Kitab Undang-Undang Hukum Pidana (selanjutnya disebut KUHP). yang antara lain terdiri dari membeli, menyewa, menukar, menyimpan atau menyembunyikan sesuatu benda. Welan (2016) mengutip pertimbangan hukum Mahkamah Agung dalam Putusan Nomor 1220 K/Pid/2016 yang menguraikan bahwa seseorang dapat disebut bukan penadah apabila memenuhi syarat kepatutan sebagai pembeli yang beriktikad baik, yaitu kepatutan tempat umum membeli handphone, dengan harga wajar, serta ada faktur/kuitansi pembelian untuk mengetahui keabsahan asal usul barang, tidak cukup jika hanya menanyakan apakah itu bukan barang curian.

Artinya ada benang merah antara pertimbangan hukum Mahkamah Agung dalam Putusan Nomor 1220 K/Pid/2016 dengan kriteria pembeli beriktikad baik yang dimaksud dalam SEMA 4/2016, maupun konsep iktikad baik dalam lapangan hukum perdata yang seharusnya sangat luas. Persoalan harga yang wajar dalam hubungannya dengan konsep iktikad baik dari seorang pembeli ini mungkin tidak banyak dipopulerkan atau dikenal secara umum, dan lebih menjadi perhatian dalam paradigma hukum pidana. Konsep ini juga sangat penting untuk ditekankan dalam hukum
Vol. 5. No. 2 Maret 2021

p-ISSN: 2598-9944 e- ISSN: 2656-6753

perdata. Perikatan yang terjadi antara penjual dan pembeli cenderung berada pada ranah hukum perdata, sehingga jika terjadi kerugian bagi para pihak terkait maka kerugian tersebut adalah kerugian pribadi dari para pihak.

Hal yang sama tentu berlaku terhadap kasus a quo. Apabila B memang seorang pembeli yang beriktikad baik, B sudah seharusnya curiga terhadap A yang menawarkan dan kemudian menjual beberapa unit mobil kepada B dengan harga yang jauh di bawah harga pasaran, sehingga menjadi harga yang tidak wajar atau tidak masuk akal. Kasus-kasus demikian ini sebenarnya juga bukan kasus yang tergolong baru atau langka, sehingga B seharusnya sudah memiliki cukup pengetahuan dan patut menduga bahwa mobil-mobil yang dijual kepadanya itu bisa saja diperoleh dari hasil kejahatan.

Apabila B berniat menuntut A ke pengadilan untuk memberi ganti kerugian atas dasar wanprestasi, maka perlu diperhatikan juga iktikad dari B seperti yang telah diuraikan sebelumnya. Iktikad baik dari B justru akan dipertanyakan di muka pengadilan karena B telah membeli mobil-mobil tersebut dengan harga yang tidak wajar. Persoalan A yang beriktikad tidak baik karena membuat kesepakatan dengan adanya kebohongan atau penipuan memang telah merugikan $\mathrm{B}$ sebagai pembeli. Namun dari sisi B sebagai pembeli, harus dilihat juga bahwa B seharusnya memiliki rasionalitas dan pengetahuan akan kepatutan di masyarakat secara umum. Rasionalitas dan kepatutan yang dimaksud adalah bahwa seharusnya mobil tidak mungkin dijual sedemikian murah apabila bukan berasal dari hasil kejahatan. B bisa saja kehilangan haknya untuk menuntut ganti rugi yang ia dalilkan telah ditimbulkan dari perbuatan A, mengingat majelis hakim tentu juga mempertimbangkan apakah B merupakan seorang pembeli yang beriktikad baik atau tidak. 
Jurnal Ilmu Sosial dan Pendidikan

http://ejournal.mandalanursa.org/index.php/JISIP/index

Terakreditasi Peringkat 5 (No. SK: 85/M/KPT/2020)

\section{KESIMPULAN}

Seorang pembeli seharusnya memiliki rasionalitas dan pengetahuan atas kepatutan yang ada di masyarakat. Pembeli seharusnya mampu menduga dan memiliki kecurigaan atas barang-barang atau benda yang dijual dengan harga yang tidak wajar atau tidak masuk akal. Dalam kasus a quo jika B memang pembeli yang beriktikad baik, seharusnya B yang mendapat penawaran dari A atas sejumlah unit mobil dengan harga yang tidak wajar, mempertanyakan asal usul mobil tersebut. Bahkan B seharusnya menolak penawaran tersebut. Dalam SEMA 4/2016, telah diberikan beberapa kriteria atas pembeli yang beriktikad baik dalam konteks jual beli tanah. Kriteria tersebut pada hakikatnya dapat diadopsi dalam konsep jual beli secara umum, terutama terkait pembelian dengan harga yang wajar. Jika B berusaha mempermasalahkan apa yang dilakukan A secara perdata dengan dasar wanprestasi, maka B harus sadar dengan konsekuensi bahwa dalam konteks persoalan tersebut $\mathrm{B}$ juga berada pada posisi pembeli yang beriktikad buruk karena bersedia membeli mobil yang ditawarkan dengan harga yang tidak wajar. Bahkan B berpotensi disangkakan delik penadahan yang dirumuskan dalam Pasal 480 ke-1 KUHP, sebagaimana pernah diuraikan di pertimbangan hukum Mahkamah Agung dalam Putusan Nomor $1220 \mathrm{~K} / \mathrm{Pid} / 2016$, bahwa pembelian dengan harga yang wajar termasuk sebagai salah satu kriteria untuk menentukan seorang pembeli sebagai pembeli yang beriktikad baik.

\section{DAFTAR PUSTAKA}

Budiono, Herlien. 2011. Ajaran Umum Hukum Perjanjian dan Penerapannya di Bidang Kenoariatan. Bandung: Citra Aditya Bakti.

Hernoko, Agus Yudha. 2008. Hukum Perjanjian Asas Proporsionalitas dalam Kontrak Komersial. Yogyakarta: Mediatama.
Vol. 5. No. 2 Maret 2021

p-ISSN: 2598-9944 e- ISSN: 2656-6753

Kartini Muljadi dan Gunawan Widjaja. 2003. Perikatan yang Lahir dari Perjanjian. Jakarta: Raja Grafindo Persada.

Khairandy, Ridwan. 2004. Iktikad Baik dalam Kebebasan Berkontrak. Jakarta: UI Press.

Marzuki, P. M. 2016. Penelitian Hukum Edisi Revisi. Jakarta: Prenada Media Group.

Pramono, Nindyo. 2020. Hukum Bisnis (Edisi 2). Tangerang Selatan: Universitas Terbuka.

Subekti, R. 2014. Aneka Perjanjian. Bandung: Aditya Bakti.

Soeroso, R. 2006. Pengantar Ilmu Hukum. Jakarta: Sinar Grafika.

. 2011. Perjanjian di Bawah Tangan: Pedoman Praktis Pembuatan dan Aplikasi Hukum, Jakarta: Sinar Grafika.

Welan, Riski David. 2018. Tindak Pidana Penadahan dalam Pasal $480 \mathrm{ke-1}$ KUHP (Kajian Terhadap Putusan Mahkamah Agung Nomor 1220 K/Pid/2016). Jurnal Lex Crimen, Vol. VII No. 6.

Webinar Nasional "Implikasi Corona Virus Disease 2019 (COVID-19) dalam Perjanjian Pembiayaan", 2020, Kerjasama Fakultas Hukum Universitas Dr. Soetomo Surabaya dengan Asosiasi Pengajar Hukum Keperdataan (APHK). 